\title{
Hepatic mRNA expression and plasma levels of insulin-like growth factor-I (IGF-I) in broiler chickens selected for different growth rates
}

\author{
Poliana Fernanda Giachetto ${ }^{1}$, Eduardo Correa Riedel ${ }^{1}$, Jane Eyre Gabriel ${ }^{1}$, Maria Inês Tiraboschi Ferro ${ }^{1}$, \\ Sônia Marli Zingaretti Di Mauro ${ }^{1}$, Marcos Macari ${ }^{2}$ and Jesus Aparecido Ferro ${ }^{1}$ \\ ${ }^{1}$ Universidade Estadual Paulista, Faculdade de Ciências Agrárias e Veterinárias, \\ Departamento de Tecnologia, Laboratório de Bioquímica e Biologia Molecular, Jaboticabal, SP, Brazil. \\ ${ }^{2}$ Universidade Estadual Paulista, Faculdade de Ciências Agrárias e Veterinárias, \\ Departamento de Morfologia e Fisiologia Animal, Jaboticabal, SP, Brazil.
}

\begin{abstract}
The hepatic expression and plasma concentrations of IGF-I were investigated in three broiler chicken strains selected for different growth rates (HP-Hubbard-Pettersen, a fast growing strain; NN-Naked-neck, a strain with an intermediate growth rate and a heterozygous genotype, and C-Caipira, a slow growing crossbred strain). The chickens were studied at 1,21 and 42 days of age and had free access to food throughout the study. Hepatic IGF-I mRNA expression was assessed by dot blot analysis using a randomly labeled chicken IGF-I cDNA as the probe and plasma IGF-I concentrations were assayed by radioimmunoassay. The hepatic levels of IGF-I mRNA increased from 1 to 21 days of age in all strains, with NN chickens showing a higher $(p<0.05)$ IGF-I expression than the other strains. Plasma IGF-I concentrations increased $(p<0.05)$ with broiler chicken age, but there were no significant differences among the strains. These results indicate that despite differences in the growth rates among the strains, the changes in the expression of IGF-I mRNA in liver and in the plasma levels of IGF-I were independent of broiler chicken strain, but varied with chicken age.
\end{abstract}

Key words: IGF-I mRNA, broiler chicken, growth performance, plasma IGF-I.

Received: April 3, 2003; Accepted: September 2, 2003.

\section{Introduction}

Insulin-like growth factor-I (IGF-I) is a highly conserved, 70 amino acid, single-chain polypeptide that plays an important role in the control of growth and metabolism in chickens and mammals (Dawe et al., 1988; Florini et al., 1996). Growth and differentiation are stimulated when exogenous IGF-I is injected into chicken embryos (Girbau et al., 1987), but after hatching, the gene expression and plasma concentration of IGF-I increase with age and then decline between 6 and 7 weeks of age (Huybrechts et al., 1985; Johnson et al., 1990; McGuinness and Cogburn, 1990). The plasma levels of IGF-I vary with the nutritional state since chickens fed a low protein diet have a low plasma content of this polypeptide (Rosebrough et al., 1992; Rosebrough and McMurtry, 1993).

Send correspondence to Jesus Aparecido Ferro. Universidade Estadual Paulista, Faculdade de Ciências Agrárias e Veterinárias, Departamento de Tecnologia. Via de Acesso Prof. Paulo Donato Castellane, s/n. 14884-900 Jaboticabal, SP, Brazil. E-mail: jesus@fcav.unesp.br.
Although much is known about the mechanisms involved in the synthesis and secretion of GH and its regulatory effect on IGF-I production, various aspects about the role of $\mathrm{GH}$ and its interactions with its receptors require clarification, especially in recently improved broiler chicken strains selected for fast growth or food conversion. Contradictory data have been reported about the positive correlation between IGF-I plasma levels and growth rate. Scanes et al. (1989) reported higher IGF-I plasma levels in strains selected for heavy body weight and Beccavin et al. (2001) found an association between high growth rates and higher levels of hepatic IGF-I mRNA and circulating IGF-I. However, Goddard et al. (1988) and Leenstra et al. (1991) found no difference in plasma IGF-I levels in strains selected for food conversion or weight gain.

In this work, we examined the hypothesis that broiler chickens selected for fast growth have higher liver expression of IGF-I mRNA and a higher plasma concentration of this polypeptide during growth. 


\section{Material and Methods}

\section{Selection, housing and management of chickens}

Six hundred one-day-old male and female broiler chicks from three strains (200 birds per strain) were used. The strains were: Hubbard-Pettersen (HP), a commercial strain selected for fast growth, Naked-neck (NN), a strain with the heterozygous genotype Nana selected for medium weight gain and Caipira $(C)$, a native crossbred strain with a very low growth rate.

The birds were housed on the floor in separate boxes at a temperature close to thermoneutrality for each age interval. Thus, the initial temperature was $33{ }^{\circ} \mathrm{C}$ and decreased at a rate of $2{ }^{\circ} \mathrm{C}$ per week to $23^{\circ} \mathrm{C}$ at 35 days of age. The birds were fed ad libitum with diets containing $3,100 \mathrm{kcal}$ of metabolizable energy (ME)/kg that consisted of corn and soybean meal with a vitamin-mineral supplement (Table 1). From 1-21 and 22-42 days of age, the birds were fed diets containing $21.8 \%$ and $19.8 \%$ of crude protein $(\mathrm{CP})$, respectively.

The growth curve for each strain was determined by weighing the birds at 1, 7, 21,35 and 42 days of age. Food intake was also measured, and food conversion was calculated for each strain for the initial (1-21 days), final (22-42 days) and total (1-42 days) periods.

\section{Liver sampling}

To assess IGF-I mRNA expression, three males of each strain were sacrificed by cervical dislocation at 1,21 and 42 days of age and 1 gram of liver was quickly collected and frozen in liquid nitrogen. The samples were stored at $-80^{\circ} \mathrm{C}$ until total RNA isolation.

Table 1 - Composition (in \%) of the diets used.

\begin{tabular}{lcc}
\hline Ingredients & $\begin{array}{c}\text { Starting diet } \\
(1-21 \text { days of age })\end{array}$ & $\begin{array}{c}\text { Final diet } \\
(22-42 \text { days of age })\end{array}$ \\
\hline Corn & 51.28 & 58.20 \\
Soybean meal & 38.35 & 32.63 \\
Soybean oil & 5.37 & 4.17 \\
Vitamin-mineral mix ${ }^{1}$ & 5.00 & 5.00 \\
Total & 100.00 & 100.00 \\
Calculated values: & & \\
Crude protein (g) & 21.85 & 19.83 \\
Metabolizable energy & 3099.19 & 3099.38 \\
(kcal/kg) & & \\
\hline
\end{tabular}

${ }^{1}$ Vitamin and mineral mix/kg: vitamin A $176,000 \mathrm{IU}$, vitamin D3 40,000IU, vitamin E $500 \mathrm{mg}$, vitamin K3 $100 \mathrm{mg}$, vitamin B1 $36 \mathrm{mg}$, vitamin B2 $200 \mathrm{mg}$, vitamin B6 $50 \mathrm{mg}$, vitamin B12 $560 \mathrm{mg}$, niacin $700 \mathrm{mg}$, biotin $3 \mathrm{mg}$, pantothenic acid $500 \mathrm{mg}$, folic acid $30 \mathrm{mg}$, clostrain chloride $20 \mathrm{mg}$, iron $1100 \mathrm{mg}$, copper $300 \mathrm{mg}$, manganese $1800 \mathrm{mg}$, zinc $1200 \mathrm{mg}$, iodine $24 \mathrm{mg}$, selenium $3 \mathrm{mg}$, methionine $20 \mathrm{~g}$, calcium $176 \mathrm{~g}$, phosphorus $68 \mathrm{~g}$, sodium $23 \mathrm{~g}$, chloride $36 \mathrm{~g}$, growth promoter $2 \mathrm{~g}$, coccidiostatic $10 \mathrm{~g}$, BHT $1 \mathrm{~g}$.

\section{Blood sampling and IGF-I assay}

Blood samples $(5 \mathrm{~mL})$ from male chickens $(\mathrm{n}=12)$ were obtained by venipuncture (brachial vein) using a heparinized syringe. The blood was centrifuged at $3,000 \mathrm{rpm}$ and $4{ }^{\circ} \mathrm{C}$ for $10 \mathrm{~min}$. The plasma was collected and stored at $-20^{\circ} \mathrm{C}$ until assayed for IGF-I. Following the precipitation of plasma binding proteins (IGFBPs) with acidified ethanol, plasma IGF-I was quantified using a heterologous radioimmunoassay (RIA) previously validated for chicken plasma (Huybrechts et al. 1985).

For IGFBP precipitation, $400 \mu \mathrm{L}$ of an ethanol- $\mathrm{HCl}$ solution ( $2 \mathrm{~N} \mathrm{HCl}, 95 \%$ ethanol) were added to a tube containing $100 \mu \mathrm{L}$ of plasma. After vortex-mixing, the tubes were incubated at room temperature for $30 \mathrm{~min}$ and then centrifuged at $3,000 \mathrm{xg}$ for $30 \mathrm{~min}$, at $4{ }^{\circ} \mathrm{C}$. After centrifugation, an aliquot $(200 \mu \mathrm{L})$ of each supernatant was collected without disturbing the precipitates and was thoroughly mixed with $80 \mu \mathrm{L}$ of neutralizing solution $(0.855 \mathrm{M}$ Tris) followed by incubation for $60 \mathrm{~min}$ at room temperature. After a further centrifugation $(3,000 \times \mathrm{g}, 60 \mathrm{~min}$, $4{ }^{\circ} \mathrm{C}$ ), a $100 \mu \mathrm{L}$ aliquot was removed for IGF-I quantification.

For RIA, $1 \mu \mathrm{g}$ of recombinant human IGF-I (hIGF-I) in $0,1 \%$ acetic acid was iodinated with $1 \mathrm{mCi}\left[{ }^{125} \mathrm{I}\right] \mathrm{NaI}$ (Amersham Biosciences) by adding chloramine $\mathrm{T}$ $(0.1 \mathrm{mg} / \mathrm{mL}$ in $0.3 \mathrm{M}$ sodium phosphate buffer, $\mathrm{pH} 7.6)$ in a stepwise manner over a period of $4.5 \mathrm{~min}$. The iodination reaction was terminated by adding to the reaction mixture $150 \mu \mathrm{L}$ of a solution containing $1.0 \mathrm{M} \mathrm{NaI}, 100 \mathrm{mM}$ $\mathrm{KH}_{2} \mathrm{PO}_{4}, 0,1 \%$ BSA and $0.02 \% \mathrm{NaN}_{3}$. Iodinated peptide was separated from free ${ }^{125} \mathrm{I}$ by chromatography on a Sephadex G-50 column pre-equilibrated and eluted with $30 \mathrm{mM} \mathrm{NaH}_{2} \mathrm{PO}_{4}$ containing $0.25 \%$ BSA. The specific activity of the purified $\left[{ }^{125} \mathrm{I}\right]-\mathrm{hIGF}-\mathrm{I}$ was $\sim 320 \mu \mathrm{Ci} / \mu \mathrm{g}$. Sodium phosphate buffer ( $30 \mathrm{mM}, \mathrm{pH} 7.5)$, containing $10 \mathrm{mM}$ EDTA, $0.02 \%$ protamine sulphate and $0.02 \%$ sodium azide was used to dilute the primary and secondary antibodies and the hormone standard for the assay. Standard hormone (hIGF-I) and tracer $\left({ }^{125}\right.$ I-labelled hIGF-I) were initially dissolved, diluted and stored in phosphate buffer containing $0,1 \%$ BSA. The RIA diluent was the phosphate buffer described above containing $0.05 \%(\mathrm{v} / \mathrm{v})$ Tween 20 .

The assay was done under nonequilibrium conditions. On day 1 , RIA diluent $(250 \mu \mathrm{L})$ plus a $50 \mu \mathrm{L}$ sample of the acid-ethanol extract and $100 \mu \mathrm{L}$ of tracer containing ${ }^{125}$ I-labelled hIGF-I $(6,000 \mathrm{cpm})$ were added to RIA tubes containing $100 \mu \mathrm{L}$ of primary antibody (1:16,000 working dilution), followed by mixing and incubation for $24 \mathrm{~h}$ at room temperature. On day 2 , secondary antibody $(100 \mu \mathrm{L}$ of goat anti-rabbit IgG diluted 1:25 in phosphate buffer) plus $100 \mu \mathrm{L}$ of carrier solution ( $49 \mathrm{~mL}$ of RIA buffer, $1 \mathrm{~mL}$ of normal rabbit serum, $1.5 \mathrm{~g}$ of polyethylene glycol) were added to each tube, followed by vortex-mixing and 
centrifugation at $2,000 \mathrm{x} \mathrm{g}$ for $30 \mathrm{~min}$ at $4{ }^{\circ} \mathrm{C}$. Subsequently, $1 \mathrm{~mL}$ of $1 \mathrm{M} \mathrm{NaCl}$ and $6 \%$ polyethylene glycol were added and incubated at $4{ }^{\circ} \mathrm{C}$ for $10 \mathrm{~min}$ followed by centrifugation at $2,000 \times \mathrm{g}$ for $30 \mathrm{~min}$. The resulting supernatant was aspirated and the pellet counted in a $\gamma$-counter. The intra-assay coefficient of variation was $6.9 \%$.

\section{Dot blot analysis of IGF-I mRNA expression}

Frozen hepatic tissue $(1 \mathrm{~g} / \mathrm{bird})$ was homogenized, and total RNA was isolated by the guanidinium thiocyanate method of Chomczynski and Sacchi (1987). Total RNA was quantified by the absorbance at $260 \mathrm{~nm}$ and the relative IGF-I mRNA content was determined by dot blot hybridization. Briefly, $20 \mu \mathrm{g}$ of total RNA were dried under vacuum and dissolved in $25 \mu \mathrm{L}$ of $50 \%$ DMSO (dimethyl sulphoxide), $10 \mathrm{mM}$ sodium phosphate, $\mathrm{pH} 7.0$ and $1.0 \mathrm{M}$ glyoxal. After incubation at $50{ }^{\circ} \mathrm{C}$ for $1 \mathrm{~h}$, the samples were placed on dry ice. Two dilutions of $5 \mu \mathrm{g}$ and $10 \mu \mathrm{g}$ of RNA were prepared in a final volume of $400 \mu \mathrm{L}$ of TE $(10 \mathrm{mM}$ Tris-HCl, $1 \mathrm{mM}$ EDTA, $\mathrm{pH}$ 8.0) and dotted (Bio-Dot Microfiltration Apparatus, Bio-Rad) onto nylon membranes (Hybond N, Amersham Pharmacia Biotech). The membranes were pre-hybridized for $2 \mathrm{~h}$ at $65{ }^{\circ} \mathrm{C}$ in a pre-hybridization solution ( $1 \%$ BSA fraction $\mathrm{V}, 7 \%$ sodium dodecyl sulphate, $1 \mathrm{mM}$ EDTA, $0.5 \mathrm{M}$ sodium phosphate, $\mathrm{pH}$ 7.2), with $20 \mathrm{~mL}$ per $100 \mathrm{~cm}^{2}$, and hybridized for $16 \mathrm{~h}$ at $65^{\circ} \mathrm{C}$ with the same solution containing a randomly labeled (Feinberg and Vogelstein, 1983) cDNA probe for chicken IGF-I (cloned into the pGEM-3Z plasmid and kindly provided by Dr. Peter S. Rotwein (School of Medicine, Washington University)). After hybridization, the membranes were washed twice in wash A solution $(0.5 \%$ BSA, $5 \%$ SDS, $1 \mathrm{mM}$ EDTA, $40 \mathrm{mM}$ sodium phosphate, $\mathrm{pH}$ 7.2) at $65^{\circ} \mathrm{C}$ for $30 \mathrm{~min}$. Autoradiography was done using Kodak X-OMAT X-ray film and Dupont Cronex Lightening Plus intensifying screens. For re-probing, the membranes were washed in $10 \mathrm{mM}$ Tris- $\mathrm{HCl}$ at $90^{\circ} \mathrm{C}$ for $20 \mathrm{~min}$ and then re-hybridized with a cDNA probe for rat 28S RNA under the same conditions as used for IGF-I cDNA. The signals obtained in the dots were quantified by densitometry (GS 300 densitometer, Hoefer Scientific Instruments) and the values were normalized according to the 28S RNA hybridization signal, used as an RNA quantity and quality control for each sample. The densitometric values obtained were within the linear range of the method.

\section{Statistical analysis}

The experiments were done using a split-plot design with strains as parcels and age as sub-parcels. The data were analyzed using the general linear model procedure (GLM) and means were compared by the Tukey test using SAS software (SAS Institute, 2000).

\section{Results}

Table 2 shows the mean body weight from 1 to 42 days of age for the three strains studied. As expected, broiler chickens of the fast growing strain (HP) grew faster than the $\mathrm{NN}$ and $\mathrm{C}$ strains ( $\mathrm{NN}$ also grew faster than $\mathrm{C}$ ). The hatching body weight was higher $(\mathrm{p}<0.05)$ in HP broilers than in the other strains ( $\mathrm{HP}>\mathrm{NN}=\mathrm{C}$ ). This difference could be attributed not only to genotype, but also to the nutritional status and age of the chickens. From seven days of age, the three strains differed in body weight $(\mathrm{p}<0.05)$, with HP birds always being the heaviest, followed by NN and $\mathrm{C}$ birds.

The weight gain of the HP strain paralleled the better food conversion values (Table 3 ), but only during the initial phase (1-21 days), when HP had a significantly lower food conversion than NN birds $(1.50$ vs. $1.65, \mathrm{p}<0.05)$. During the final phase (22-42 days), food conversion was not different $(2.18$ vs. $2.24, \mathrm{p}>0.05)$ between the HP and NN strains, but both were different $(\mathrm{p}<0.05)$ from $\mathrm{C}$ birds.

Figure 1 shows the autoradiographic signals of the dot blots for hepatic IGF-I mRNA and 28S cDNA, the latter used as an internal control. The dots correspond to ages of 1,21 and 42 days. The relative densitometric values for the dots at the three different ages (expressed as arbitrary units) are shown in Table 4. Regardless of the broiler strain, hepatic IGF-I mRNA expression increased with age, from hatching to 21 days old. From 21 to 42 days, a decrease $(\mathrm{p}<0.05)$ in IGF-I mRNA expression was seen in the NN strain. A comparative analysis among strains showed that NN had a much higher hepatic IGF-I mRNA expression than the other two strains at the age of 21 days $(\mathrm{NN}>\mathrm{HP}>\mathrm{C})$.

The plasma IGF-I concentrations for the three strains at different ages are shown in Table 4 . The broiler strain did not affect the levels of circulating IGF-I but, as observed for IGF-I mRNA expression, plasma IGF-I levels increased from 1 to 21 days of age with no significant change thereafter (days 21 to 42 ).

Table 2 - Mean body weight (g) of the three strains (Hubbard-Pettersen, Naked-neck and Caipira) during the 42 days of the experiment.

\begin{tabular}{lrrrrr}
\hline & \multicolumn{5}{c}{ Strains } \\
Age (days) & \multicolumn{1}{c}{$\mathrm{HP}^{1}$} & \multicolumn{1}{c}{$\mathrm{NN}$} & \multicolumn{1}{c}{$\mathrm{C}$} & F values & CV (\%) \\
\hline 1 & $43.8^{\mathrm{a} 2}$ & $36.9^{\mathrm{b}}$ & $35.2^{\mathrm{b}}$ & 83.8 & 2.58 \\
7 & $139.2^{\mathrm{a}}$ & $81.3^{\mathrm{b}}$ & $69.7^{\mathrm{c}}$ & 306.8 & 4.40 \\
21 & $740.9^{\mathrm{a}}$ & $333.3^{\mathrm{b}}$ & $201.7^{\mathrm{c}}$ & 838.4 & 4.57 \\
35 & $1,573.0^{\mathrm{a}}$ & $656.0^{\mathrm{b}}$ & $363.1^{\mathrm{c}}$ & $1,917.7$ & 3.34 \\
42 & $2,070.5^{\mathrm{a}}$ & $911.0^{\mathrm{b}}$ & $527.0^{\mathrm{c}}$ & $1,352.4$ & 3.74 \\
\hline
\end{tabular}

${ }^{1}$ HP: Hubbard-Pettersen; NN: Naked-neck, C: Caipira. ${ }^{2}$ Means followed by the same letter in the rows are not significantly different $(p>0.05)$. 
Table 3 - Mean weight gain (g), food intake (g) and food conversion during the initial (1-21 days), final (22-42 days) and total (1-42 days) experimental periods for the three broiler chicken strains used.

\begin{tabular}{|c|c|c|c|c|c|c|}
\hline \multirow[b]{2}{*}{ Variable } & \multirow[b]{2}{*}{$\begin{array}{l}\text { Period } \\
\text { (days) }\end{array}$} & \multicolumn{3}{|c|}{ Strains } & \multirow[b]{2}{*}{$\begin{array}{c}\mathrm{F} \\
\text { value }\end{array}$} & \multirow[b]{2}{*}{$\begin{array}{l}\text { CV } \\
(\%)\end{array}$} \\
\hline & & $\mathrm{HP}^{1}$ & $\mathrm{NN}$ & $\mathrm{C}$ & & \\
\hline \multirow{3}{*}{$\begin{array}{l}\text { Body } \\
\text { weight (g) }\end{array}$} & $1-21$ & $697.1^{\mathrm{a} 2}$ & $296.5^{b}$ & $167.4^{\mathrm{c}}$ & 896.7 & 4.77 \\
\hline & $22-42$ & $1,329.6^{\mathrm{a}}$ & $577.7^{\mathrm{b}}$ & $325.3^{\mathrm{c}}$ & $1,547.0$ & 3.57 \\
\hline & $1-42$ & $2,020.7^{\mathrm{a}}$ & $874.1^{\mathrm{b}}$ & $491.8^{c}$ & $1,382.6$ & 3.80 \\
\hline \multirow{3}{*}{$\begin{array}{l}\text { Food } \\
\text { intake (g) }\end{array}$} & $1-21$ & $1,044.7^{\mathrm{a}}$ & $490.1^{\mathrm{b}}$ & $433.2^{c}$ & 688.5 & 3.93 \\
\hline & $22-42$ & $2,893.6^{\mathrm{a}}$ & $1,296.1^{\mathrm{b}}$ & $964.0^{c}$ & $1,196.6$ & 3.47 \\
\hline & $1-42$ & $3,938.2^{\mathrm{a}}$ & $1,786.2^{\mathrm{b}}$ & $1,397.2^{\mathrm{c}}$ & $1,144.6$ & 3.41 \\
\hline \multirow{3}{*}{$\begin{array}{l}\text { Food } \\
\text { conversion }\end{array}$} & $1-21$ & $1.50^{\mathrm{c}}$ & $1.65^{\mathrm{b}}$ & $2.61^{\mathrm{a}}$ & 346.0 & 3.35 \\
\hline & $22-42$ & $2.18^{\mathrm{b}}$ & $2.24^{\mathrm{b}}$ & $2.97^{\mathrm{a}}$ & 78.1 & 4.07 \\
\hline & $1-42$ & $1.94^{\mathrm{b}}$ & $2.05^{\mathrm{b}}$ & $2.85^{\mathrm{a}}$ & 146.3 & 3.06 \\
\hline
\end{tabular}

${ }^{1}$ HP: Hubbard-Pettersen; NN: Naked-neck, C: Caipira. ${ }^{2}$ Means followed by the same letter in the rows are not significantly different ( $\left.\mathrm{p}>0.05\right)$.

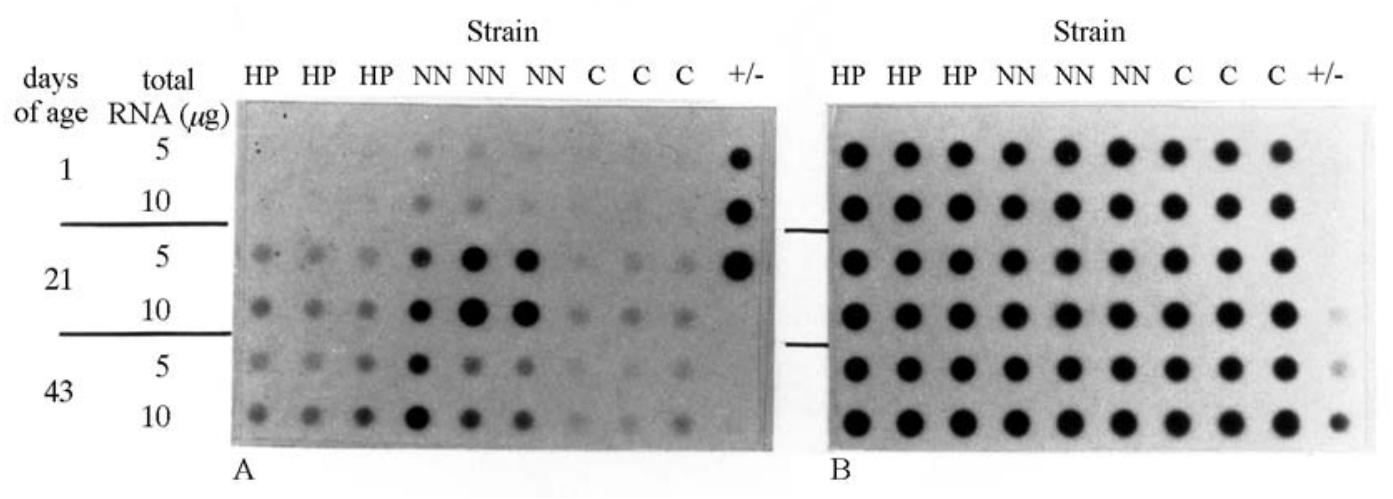

Figure 1 - Liver IGF-I mRNA expression in male broiler chickens. (A) Autoradiograph from liver total RNA dot blot hybridized with chicken IGF-I cDNA probe. (B) Autoradiograph of the same dot blot hybridized with rat RNA 28S cDNA. HP: Hubbard-Pettersen, NN: Naked-neck, C: Caipira. +/-: 1, 2 and $4 \mathrm{ng}$ of positive and negative control (pGEM-3Z plasmid containing the chicken IGF-I cDNA insert and rat 28S RNA cDNA, respectively). Total RNA from three different birds of each strain, at the specified age, was blotted on the membrane.

Table 4 - Relative values for hepatic IGF-I mRNA expression and plasma IGF-I concentrations in the three strains at 1,21 and 42 days of age.

\begin{tabular}{|c|c|c|c|}
\hline \multirow[t]{2}{*}{ Age (days) } & \multicolumn{3}{|c|}{ Strains } \\
\hline & $\mathrm{HP}^{1}$ & NN & $\mathrm{C}$ \\
\hline & \multicolumn{3}{|c|}{ Hepatic IGF-I mRNA expression (arbitrary units), $n=3$} \\
\hline 1 & $0.707^{\mathrm{Ba} 2}$ & $1.017^{\mathrm{Ba}}$ & $0.707^{\mathrm{Ba}}$ \\
\hline 21 & $2.193^{\mathrm{Ab}}$ & $4.553^{\mathrm{Aa}}$ & $1.525^{\mathrm{Ab}}$ \\
\hline 42 & $2.226^{\mathrm{Ab}}$ & $3.023^{\mathrm{Aa}}$ & $1.600^{\mathrm{Ac}}$ \\
\hline \multicolumn{4}{|c|}{ Plasma IGF-I concentration (ng/mL), $\mathrm{n}=12$} \\
\hline 1 & $5.20^{\mathrm{Ba}}$ & $7.47^{\mathrm{Ba}}$ & $4.33^{\mathrm{Ba}}$ \\
\hline 21 & $30.31^{\mathrm{Aa}}$ & $29.68^{\mathrm{Aa}}$ & $29.38^{\mathrm{Aa}}$ \\
\hline 42 & $26.09^{\mathrm{Aa}}$ & $30.34^{\mathrm{Aa}}$ & $26.98^{\mathrm{Aa}}$ \\
\hline
\end{tabular}

${ }^{1}$ HP: Hubbard-Pettersen; NN: Naked-neck, C: Caipira. ${ }^{2}$ Means with similar capital letters in the columns and lower case in the rows are not significantly different $(\mathrm{p}>0.05)$.

\section{Discussion}

As expected, the HP and NN birds had better growth performances than the $\mathrm{C}$ strain. At 42 days of age, body weight was significantly different among the three strains, thus confirming the growth potential of the genetically improved strains. Despite the increase in body weight, food conversion was not different for HP and NN strains after 21 days. Thus, the regulatory mechanisms involved in growth seem to be dependent on the genetic characteristics of the strains and also on the age of the birds.

Burnside and Cogburn (1992) reported that the hepatic expression of IGF-I mRNA in broiler chickens peaked at 28 days of age, and Beccavin et al. (2001) found that high growth rate birds had a five-fold increase in IGF-I expression from the first to sixth week of life. The plasma concentration of IGF-I was reported to increase progres- 
sively until the third week of age, and reached a plateau by the seventh week (McGuiness and Cogburn, 1990; Beccavin et al., 2001). As already observed by others (Kikuchi et al., 1991; Burnside and Cogburn, 1992; Radecki et al., 1997; Beccavin et al., 2001), the hepatic IGF-I mRNA expression and IGF-I plasma levels in the present study also increased from hatching to day 21, with hepatic expression increasing at least three-fold and plasma levels showing a six- to seven-fold increase. Nevertheless, at 42 days of age, both the expression and plasma IGF-I levels showed no significant increase $(p>0.05)$ when compared to 21 days, although other reports have indicated that this increase persisted until six weeks of age (McGuiness and Cogburn, 1990; Burnside and Cogburn, 1992; Beccavin et al. 2001).

The most interesting finding of this study was that the patterns of increase in IGF-I expression and production were the same, irrespective of the broiler chicken strain, except for the NN strain, which had higher values at all ages, but also showed reduced IGF-I mRNA expression from 21 to 42 days of age. Huybrechts et al. (1987) and Goddard et al. (1988) observed no positive correlation between growth rate and absolute plasma IGF-I levels in chickens. Our results also showed that there was no clear correlation between the growth of the birds and hepatic IGF-I mRNA expression and plasma IGF-I levels.

In mice, complete disruption of the liver IGF-I gene in the post-natal period decreased the circulating IGF-I levels by $75 \%$, while the growth rate was normal (Yakar et al., 1999). According to Oudin et al. (1998), there were no differences in the number, affinity or tyrosine kinase activity of IGF-I receptors purified from the muscles of fast and slow growth chickens at one to seven weeks of age. Thus, the difference in body weight among strains may be related to the hypothalamic-pituitary feedback mechanism that interferes with GH synthesis and release. This aspect requires further investigation, as does the genetic variation in muscle IGF-I gene expression, especially since a paracrine action of IGF-I on chicken muscle has been reported (Duclos et al., 1999).

The temporal regulation of IGF-I expression in broiler chickens of unrelated genotypes and different growth rates has been studied (Goddard et al., 1988; Ballard et al., 1990; Johnson et al., 1990), but no influence of strain was reported. In contrast, in work with chickens of different genotypes and high or low growth rates, Scanes et al. (1989) found that plasma IGF-I levels were lower in the low compared to high weight strains. Becavin et al. (2001) also found that high growth rate birds had higher levels of hepatic IGF-I mRNA and plasma IGF-I. Thus, the increased hepatic IGF-I mRNA expression observed here, which was associated with age but not strain, could be related to the complex regulatory mechanisms of growth in birds. Liver GHR (growth hormone receptor) expression is low after hatching, but increases with age (Burnside and
Cogburn, 1992; Scanes et al., 1996; Mao et al., 1998). In fast growing broilers, increased hepatic GHR expression was observed between the first and the fourth week of age and coincided with an increase in IGF-I mRNA expression and plasma IGF-I levels (Leung et al., 1987). The subsequent decrease in plasma $\mathrm{GH}$, also described by McCann-Levorse et al. (1993), does not appear to interfere with the hepatic GHR since the number and affinity of these receptors compensates for the low level of circulating $\mathrm{GH}$, thereby maintaining the steady-state expression of IGF-I mRNA.

These results show that the ontogenetic pattern of hypothalamic-pituitary axis activity after hatching is apparently independent of broiler chicken strain, despite the magnitude of the difference in their growth response. Together with previous reports (Leili et al. 1997; Beccavin et al. 1999, 2001), our findings indicate that additional temporal regulatory mechanisms related to nutrition and age are involved in modulating the expression of hepatic IGF-I mRNA and the consequent increase in plasma IGF-I levels.

\section{Acknowledgments}

This work was supported by grants from FAPESP, PADCT and CNPq. E. C. Riedel was supported by a master's fellowship from CNPq.

\section{References}

Ballard FJ, Johnson RJ, Owens PC, Francis GL, Upton FM, McMurtry JP and Wallace JC (1990) Chicken insulin-like growth factor-I: amino acid sequence, radioimmunoassay, and plasma levels between strains and during growth. Gen Comp Endocrinol 79:459-468.

Beccavin C, Chevalier B, Simon J and Duclos MJ (1999) Circulating insulin-like growth factors (IGF-I and II) and IGF binding proteins in divergently selected fat or lean chickens: effect of prolonged fasting. Growth Horm IGF Res 9:187194.

Beccavin C, Chevalier B, Cogburn LA, Simon J and Duclos MJ (2001) Insulin-like growth factors and body growth in chickens divergently selected for high and low growth rate. J Endocrinol 168:297-306.

Burnside J and Cogburn LA (1992) Developmental expression of hepatic growth hormone receptor and insulin-like growth factor-I mRNA in the chicken. Mol Cell Endocrinol 89:9196.

Chomczynski P and Sacchi N (1987) Single-step method of RNA isolation by acid guanidinium thiocyanate-phenolchloroform extraction. Anal Biochem 162:156-159.

Dawe SR, Francis GL, McNamara PJ, Wallace JC and Ballard FJ (1988) Purification, partial sequences and properties of chicken insulin-like growth factors. J Endocrinol 117:173181.

Duclos MJ, Beccavin C and Simon J (1999) Genetic models for the study of insulin-like growth factors (IGF) and muscle development in birds compared to mammals. Domest Anim Endocrinol 17:231-243. 
Feinberg AP and Vogelstein B (1983) A technique for radiolabeling DNA restriction endonuclease fragments to high specific activity. Anal Biochem 132:6-13.

Florini JR, Ewton DZ and Coolican SA (1996) Growth hormone and the insulin-like growth factor system in myogenesis. Endocr Rev 17:481-517.

Girbau M, Gomez JA, Lesniak MA and de Pablo F (1987) Insulin and insulin-like growth factor I both stimulate metabolism, growth, and differentiation in the postneurula chick embryo. Endocrinology 121:1477-1482.

Goddard C, Wilkie RS and Dunn IC (1988) The relationship between insulin-like growth factor-1, growth hormone, thyroid hormones and insulin in chickens selected for growth. Domest Anim Endocrinol 5:165-176.

Huybrechts LM, King DB, Lauterio TJ, Marsh J and Scanes CG (1985) Plasma concentrations of somatomedin-C in hypophysectomized, dwarf and intact growing domestic fowl as determined by heterologous radioimmunoassay. J Endocrinol 104:233-239.

Huybrechts LM, Kuhn ER, Decuypere E, Merat P and Scanes CG (1987) Plasma concentrations of growth hormone and somatomedin C in dwarf and normal chickens. Reprod Nutr Dev 27:547-553.

Johnson RJ, McMurtry JP and Ballard FJ (1990) Ontogeny and secretory patterns of plasma insulin-like growth factor-I concentrations in meat-type chickens. J Endocrinol 124:8187.

Kikuchi K, Buonomo FC, Kajimoto Y and Rotwein P (1991) Expression of insulin-like growth factor-I during chicken development. Endocrinology 128:1323-1328.

Leenstra FR, Decuypere E, Beuving G, Buyse J, Berghman L and Herremans M (1991) Concentrations of hormones, glucose, triglycerides and free fatty acids in the plasma of broiler chickens selected for weight gain or food conversion. $\mathrm{Br}$ Poult Sci 32:619-632.

Leili S, Buonomo FC and Scanes CG (1997) The effects of dietary restriction on insulin-like growth factor (IGF)-I and II, and IGF-binding proteins in chicken. Proc Soc Exp Biol Med 216:104-111.

Leung FC, Styles WJ, Rosenblum CI, Lilburn MS and Marsh JA (1987) Diminished hepatic growth hormone receptor binding in sex-linked dwarf broiler and leghorn chickens. Proc Soc Exp Biol Med 184:234-238.
Mao JNC, Burnside J, Postel-Vinay MC, Pesek JD, Chambers JR and Cogburn, LA (1998) Ontogeny of growth hormone receptor gene expression in tissue of growth-selected strains of broiler chickens. J Endocrinol 156:67-75.

McCann-Levorse LM, Radecki SV, Donoghue DJ, Malamed S, Foster DN and Scanes CG (1993) Ontogeny of pituitary growth hormone and growth hormone mRNA in the chicken. Proc Soc Exp Biol Med 202:109-113.

McGuinness MC and Cogburn LA (1990) Measurement of developmental changes in plasma insulin-like growth factor-I levels of broiler chickens by radioreceptor assay and radioimmunoassay. Gen Comp Endocrinol 79:446-458.

Oudin A, Chevalier B and Simon J (1998) Muscle insulin-like growth factor-I (IGF-I) receptors in chickens with high and low body weight: effects of age and muscle fiber type. Growth Horm IGF Res 8:243-250.

Radecki SV, Capdevielle MC, Buonomo FC and Scanes CG (1997) Ontogeny of insulin-like growth factors (IGF-I and IGF-II) and IGF-binding proteins in the chicken following hatching. Gen Comp Endocrinol 107:109-117.

Rosebrough RW and McMurtry JP (1993) Protein and energy relationships in the broiler chicken. Effects of protein quantity and quality on metabolism. Br J Nutr 70:667-678.

Rosebrough RW, McMurtry JP and Vasilatos-Younken R (1992) In vitro lipid metabolism, growth and metabolic hormone concentrations in hyperthyroid chickens. Br J Nutr 68:667676.

SAS Institute (2000). SAS (Statistical Analysis System): users' Guide. SAS Institute, Cary, 496 pp.

Scanes CG, Dunnington EA, Buonomo FC, Donoghue DJ and Siegel PB (1989) Plasma concentrations of insulin like growth factors (IGF-I) and IGF-II in dwarf and normal chickens of high and low weight selected strains. Growth Dev Aging 53:151-157.

Scanes CG, Radecki, SV and Aramburo C (1996) Growth hormone and growth factors in avian development. Poult Avian Biol Rev 7:89-98.

Yakar S, Liu JL, Stannard B, Butler A, Accili D, Sauer B and LeRoith D (1999) Normal growth and development in the absence of hepatic insulin-like growth factor I. Proc Natl Acad Sci USA 96:7324-7329.

Editor: Klaus Hartfelder 